\title{
Engaging students and academics in creating a new model for research libraries: a reflective case study on the UCL Student Centre
}

\author{
The paper will explore how the UCL Student Centre, opened in 2019, responds to \\ the emphasis on "research-based education" in the UCL Education Strategy. It \\ discusses the high levels of engagement at different levels, which characterised \\ the design of the building, and how services and spaces were designed around \\ student needs.
}

The paper will aim to provide insights on both successful characteristics and lessons learned from the construction and first year of operation of the Student Centre, to benefit library staff and designers in planning, designing and operating research library spaces. The article will also consider how the building provides a showcase for the talent and creativity of the diverse staff and student community of the university. The building has elicited a strong emotional response from students, creating a stronger sense of belonging to the UCL community and encouraging students' pro-active approach to learning.

Keywords: learning space; user engagement; project management

\section{Introduction}

In the UK, the introduction of $£ 9,000$ tuition fees in 2012 coincided with a significant increase in capital investment to improve the student experience, generally in the form of upgraded facilities. University campuses boast new buildings devoted to teaching and learning, including the Alan Gilbert Learning Commons in Manchester (£23M), the Diamond in Sheffield (£81M) and the focus of this paper, the Student Centre at UCL (£67M). For UCL (University College London), a research-intensive university with 42,000 students, one key strategic priority was to '[give] our students the best support, facilities and opportunities' (UCL, 2014). This was closely linked to a university-wide initiative to foster 'research-based education' as set out in the institutional education 
strategy (UCL, 2017). Whilst UCL had a network of 18 site libraries, there was no large-scale social learning space to meet the needs of new pedagogical approaches. The paper will explore how the Student Centre responds to the emphasis on "research-based education" in the institutional Education Strategy and the Connected Curriculum (Fung, 2017). The article will also consider how the building provides a showcase for the talent and creativity of the diverse staff and student community of the university.

The paper opens with a literature review on research-based education which establishes the role of students as active partners within the university who have a crucial role in managing their own experience. As a precedent, the UCL Cruciform Hub is used to illustrate the benefits of this approach in creating a learning and teaching centre for UCL Medical School students. The second half of the paper focuses on the Student Centre, with a brief overview of the building as an innovative collection of services and facilities targeted specifically at delivering a high-quality student experience. The paper then discusses the approach adopted to engagement with the Student Centre project. Specifically, it discusses dynamics within a project coalition, and the tensions between conducting exhaustive engagement and delivering projects in an efficient and professional manner. The experience of the Student Centre is that trust amongst the project team and stakeholders is critical to ensure that engagement can be conducted effectively and managed in a free-flowing manner as appropriate.

The paper will also explore successes and limitations. For busy estates staff and design teams, pervasive engagement can be perceived as a cause of delay or waste of time. Feedback from students has been extremely positive, and this paper refers to internal UX projects and reviews which are ongoing to understand the lessons learned from the first year of running this $£ 67 \mathrm{~m}$ building. Finally, the paper acknowledges some of the limitations of the findings given the limited period of data collection to date. One 
observation from the feedback received is that the building has elicited a strong emotional response from students, which is encouraging with regards to creating a stronger sense of belonging to the UCL community and to students' approach to learning more widely. Within UCL, the Student Centre is referenced as a model for the development of future learning space, such as those on the UCL East campus due to open in 2022.

\section{Research-based education: Students as partners}

The core principles of a university propounded by Humboldt in the $19^{\text {th }}$ century are the integration of research and teaching; the need to have freedom to teach, study, and pursue truth without hindrance. These ideals have proven extremely influential to how the academic community considers itself even today. It is not clear whether this vision has ever been fully realised (Lucas 2006: 25-6). However, many universities publicly demonstrate their philosophical commitment to Humboldtian ideals, of the integration of teaching and research, by referencing this in their mission statements and strategies (Geschwind, L and Brostöm 2015: 60).

Healey (2005) argues that students learn best when they are completely immersed in their subject and this includes engagement with research. There are different approaches to this depending on the discipline, but Healey feels the most effective is research-based education where the curriculum utilises inquiry-based learning, when students are directly involved in research activities. This enables them to contextualise and problematise their knowledge, something which Scott (2005) feels is one of the key components to the best education. Brew (2010: 141-2) also argues that the skills gained by students when interacting with research are extremely beneficial and will help them navigate our increasingly complex society. Students engaging and 
undertaking research learn to critically evaluate knowledge and make evidence-based decisions, through the collection and analysis of data or information. The researchbased education model places students at the start of the research process and infers a role for students as members of the academic community beyond that of customer. Biesta (2013) critiques the logic of economic transaction adopted by some universities, where 'customers' are pushing institutions to adapt and compete, with the resulting 'strong emphasis on reputation and relative positioning in league tables.' This is contrasted with a 'professional transactions' approach, where the professional defines what the client needs and then proceeds to service this need. Biesta advocates for a teaching university based on a 'democratic-educational model' in which 'parties engage in a process of collective needs definition based on recognition of differential expertise. This is a process in which wants are transformed into needs rather than that wants are simply taken as needs or needs are defined by those who service the needs.' In this model, 'the university does not simply give to its stakeholders what they already know they want, but gives something that, at the start, they do not know they want' (Biesta, 2013: 38). This theoretical perspective is corroborated by the findings of the UUK (Universities UK) study, which found that 'students recognise and value the unique educational relationship that they have with their university' (UUK, 2017).

Faced with the challenge of greater competition to attract students, and to address the issues identified by government around student satisfaction, many researchintensive universities introduced measures to address the student experience at an institutional level. The approach at UCL was to enhance the quality of student facilities and services, and to develop a new approach to education within the university. Unlike the data-driven reactive approach propounded by Burgess, Senior and Moores (2018), the university sought to re-balance research and education as well as involve students 
more actively in the life of the university. UCL 2034 and the UCL Education Strategy set out the university's vision of a "research-based education", where the strengths of the university's research would form part of the strengths of the educational experience for students, and students would be enabled to participate in research from the outset of their programme of study (UCL 2014, 2017). Fung (2017) describes the new approach to education which UCL adopted, styled as the Connected Curriculum. This initiative encourages individuals and teams within each discipline to think deeply about the nature and practices of their own research, and to engage students in the research process, from undergraduate to research postgraduate level. The Connected Curriculum illustrates an approach where universities define the 'student experience' as the wideranging development of students during their time at university, rather than merely as customer satisfaction (Fung, 2017: 61-63).

The emphasis of the Connected Curriculum lies in taking a holistic view of what students' educational experience should comprise. It encourages collaborative enquiry, peer to peer teamwork and dialogue between students and academics, equipping students with the skills required to solve complex challenges and the confidence and ethical standards to contribute positively in a professional environment. This requires active engagement from students in all aspects of their university experience. The development of learning spaces within UCL's libraries, to offer a wider range of spaces and particularly more social learning and group working space, enables this type of learning to happen on campus and transform the academic 'into a single point of access, uniting stakeholders on campus' (Volkmann and Stang, 2015: 236). Meunier and Eigenbrodt (2014) outline the benefits of participatory design, working in partnership with groups of stakeholders on academic library developments. One key benefit is that each group of users can understand the needs of others better, illustrating the process 
Biesta described as 'collective needs definition based on recognition of differential expertise'.

'Satisfying and mediating the demands of all interest groups is only one element among a growing range of project management issues. [...] In all sectors, user engagement in the entire project cycle, from researching learners' needs and behaviour, and to involving architects, teachers, and learners in design and evaluation procedures, is addressed excessively in the major research networks around the globe.' (Volkmann and Stang, 2015: 239)

\section{Case Study: The UCL Cruciform Hub}

When UCL's Medical School redesigned its curriculum between 2010 and 2012, the opportunity was taken to refurbish the medical library in the Cruciform building. This project was established as one of the first initiatives from the UCL Masterplan, which set out to enhance the student and staff experience (UCL, Lifschutz, Davidson, Sandilands, 2011:5). From the outset, the project was developed in collaboration between UCL medical students, academic staff and professional services teams. A Project Board was established to include, unusually for a capital estates project, the Student Sabbatical Officer for the Medical School.

The involvement of students in the project grew as the design phases progressed, with student representatives involved in a number of working groups. Presentations, workshops and meetings were arranged between the design team and groups of students. This process ran in parallel to traditional surveys of students, with over 1,000 responses received. The combination of quantitative data from the online surveys and more qualitative information from face-to-face interactions with students helped to refine the designs to suit the specific requirements of UCL Medical School students. 
Where students expressed specific requirements, such as a request for loanable laptops, the professional teams at UCL and the design team were able to work together and incorporate such features. Since not all students could or would naturally participate using typical channels, special efforts were made by the Site Librarian to engage with specific user groups via alternative means, such as Student Society newsletters. Because there was a critical mass of engaged students, the project felt like a partnership and this had a positive impact on the project team, who felt a greater sense of the value of the project to students.

The end result was not only a high-quality teaching and learning hub for the Medical School, but also a greater sense of community amongst students and staff in the Hub. To illustrate this sense of community, a few months after the new facility opened, the RUMS Medical Student Society asked whether a cabinet could be acquired to display their sports trophies in the hub. Feedback from students and staff has been overwhelmingly positive (Arthur, 2015), and the approach of involving students more closely in projects has been copied in subsequent projects, such as the Student Centre and UCL ChangeMakers, an initiative to empower students to effect changes in the university.

Student participation, as facilitated in the Cruciform Hub project, helps to develop a sense of community and a positive feeling for students and staff involved. Community engagement is presented as a crucial part of life and learning in a university environment, helping to foster knowledge exchange, and ecological and political awareness (Krause, 2009: 422). The Hub is a snapshot example of how students can play a part in shaping a better university environment, working in partnership with staff. Kahu (2013) provides a helpful overview of the breadth of perspectives which interweave when we talk about 'student engagement' and identifies the importance of 
emotions. Studies of large cohorts of students have identified 'a relationship between the ways they emotionally experience their course and the approach they take to the learning of that course. Students who more strongly experience positive emotions, such as hope and pride, and more weakly experience negative emotions (such as anger, boredom, anxiety and shame), are likely to be adopting more of a deep approach to learning' (Trigwell, Ellis and Han, 2012). A survey of the students who took part in UCL ChangeMakers in 2014-15 indicated that all the students surveyed were glad that they had taken part in the initiative and many felt it had improved their experience at UCL (86\%) (Marie, Arif and Joshi, 2016).

The creation of the Cruciform Hub at UCL provided a blueprint for how spaces could be co-created with students to deliver a high-quality, fit-for-purpose learning environment. The range of facilities and services provided in a single site, conceived around student needs, provided a basis for the concept of the Student Centre.

\section{Case Study: The UCL Student Centre}

\section{An Overview of the UCL Student Centre}

The Student Centre is situated at the new heart of the UCL campus in Bloomsbury. The building was opened on 18th February 2019 by Professor Anthony Smith as ViceProvost (Education \& Student Affairs) and the Students' Union Sabbatical Officers. The 5,764 square metre building, spread across 8 floors, was designed by Nicholas Hare Architects and built by Mace.

In addition to 1,000 learning spaces, the building contains a Prayer Room, Meditation Room, ablution facilities, showers, a Student Enquiries Centre incorporating Disability, Mental Health and Wellbeing Support, IT Helpdesk and a terrace. The Student Centre is open 24-hours, all year round and is fully accessible: 'the centre has 
been designed with extreme care and consideration for all students.' (Students' Union UCL, 2020).

The building is staffed by a team of Library Services staff and UCL Security, working closely with Student \& Registry Services and ISD staff based on the first floor. Library Services staff rove the building to help students at the point of need and can help to refer students as required to specialist services. Staff are actively seeking feedback and observing usage, as part of continuous improvement of services and facilities. The Student Enquiries Centre delivers face-to-face administrative and enquiry support.

A Service Model Working Group was established in July 2017. This remains active and is chaired by the Director of Operations in Library Services. The Group includes Library Services, Student \& Registry Services, Estates, ISD, the UCL Chaplain, UCL Culture, Communications and Marketing and the Student Sabbatical Officer for Democracy, Operations and Community.

The Group worked ahead of the opening of the building to coordinate the structure of roles and cross-training between teams based in the Student Centre. It oversaw the submission of a joint business case/operational budget for the Student Centre in 2018 and oversees policies and procedures for the building's use, in line with central UCL policies.

\section{Oversight and Management of the Project}

The governance of the project was overseen by a Project Board, chaired by the ViceProvost (Education and Student Affairs) as Project Sponsor. The board met at least monthly during the life of the project, with regular reports from the project managers and open communication. The vision for the project was clearly set and the priorities, including financial stringency, were clear to all from the outset. Having the level of 
clarity as well as representation from the key service providers at this strategic level helped discussions at other levels of the project.

One characteristic feature which was noted in the wake of the project when starting to gather initial lessons learned was the level of trust across the project coalition on this project. This supports earlier research that 'respect, openness, responsibilities and trust seem more important in creating value in design than planning and costs' (Volker, 2008). Via the Project Board and Estates monitoring procedures, there was close monitoring and formal controls on the project, ensuring that the project kept to programme and budget. The performance of the project against these traditional metrics allowed for extensive consultation to be undertaken and continued through the lifecycle of the project. This may seem paradoxical, given the risk that consultation in latter stages of the project could lead to undesirable calls for changes to be made, risking additional cost and/or time delays. Smyth (2006) provides a model for trust dynamics in the context of construction projects, which may begin to address this paradox. As consultation exercises were conducted, and feedback incorporated into emerging designs, the level of confidence in the design grew for end-users (for instance Library Services or the Students' Union). Conversely, it became increasingly apparent the UCL Estates project manager and external project managers that engagement activity could proceed with minimal impact on the programme, through setting clear boundaries on what was in scope of each phase of consultation, and indeed that the levels of risk associated with changes reduced over time, as designs were being informed by user needs. This positive loop worked to bring confidence in the parties to higher levels. Between 2013 and 2015, the project team worked with UCL Library Services to conduct a series of exhibitions, interviews and observation of students, as well as benchmarking with other institutions. AMA's 2012 survey confirmed that there were 
two major hopes from the student point of view: "study space of all kinds - social, group and quiet/silent - and facilities that offer affordable food as well as space to eat food brought from home.”

In the first term of 2017-18, furniture trials were undertaken in the Science Library, Students' Union, Cruciform Hub, Main Library and Great Ormond Street Institute of Child Health Library. These surveys informed the selection of furniture in the building. To finalise selection, the project team led design workshops and showroom visits with Sabbatical Officers between December 2017 and April 2018.

The Student Centre exemplifies how the university is delivering the institutional strategy in a number of ways, particularly around Principal Theme 2 (research-based education, underpinning an inspirational student experience) and Key Enablers A and E (giving our students the best support, facilities and opportunities; managing a sustainable estate fit for UCL's aspirations) (UCL, 2014). The project illustrates how different parts of UCL are working together, across academic leadership, Professional Services and the Students' Union, to realise a breakthrough project. According to Bacon (2019) 'UCL may well have invented a new building type for urban universities'.

Students were actively engaged in the creation of the building from its inception, as detailed below, and the Student Centre has been welcomed by UCL students and staff.

\section{Putting research-based education into practice: Co-creating with UCL students}

Unlike the Cruciform Hub, which had a clear sub-group of UCL members as its core user community, the Student Centre was conceived as a space for all 42,000 students at the university. This required a more generic approach to engagement, in the sense that it covered all academic disciplines and all phases of study. Special attention was given to the needs of postgraduate students, who represent over $50 \%$ of the UCL student 
community, so that the space would have a more 'mature' feel than some predominantly undergraduate learning spaces. The design development of the Student Centre was undertaken in partnership with UCL students and with academic input from the outset. In May 2012, Alexi Marmot Associates (AMA) undertook a survey of over 1,000 UCL students to define the priorities for the new building's brief. The project benefitted from the expertise of AMA in applying a range of methods to collect information, including focus groups, surveys and user observations in learning spaces.

The process for user engagement was not always linear or obviously managed. Some elements were 'messy', whereby consultation might occur on specific items of the brief with stakeholders and lead to unintended discoveries. For instance, in a meeting of students, Library staff and Security to discuss requirements for reception desks and help points, discussion broadened to cover the range of learning support services available from UCL, which student representatives were unaware of. This led to a communication strand of activity to raise awareness of services available to support learning through digital signage in the building. It could be argued that this lightly-managed approach to stakeholder input, as opposed to a more strictly controlled process where inputs were strictly sought from relevant experts may have contributed to some of the success on the project. Bligh (2014) provides a helpful framework to understand how traditional approaches to space design in universities can stifle potential innovation and creativity. He suggests an alternative approach, whereby members of the university community have more direct communication, rather than mediated through committee structures.

\footnotetext{
'More direct relationships will be required between the various denizens, between denizens and architects, and across the boundaries of estates departments. Rather than each participant focusing on their own fragment of the object, knotworking involves constant negotiation and rapid integration of expertise. [...] The range of different plans, including specific pedagogical briefs (Neuman 2003), being recommended in both the estates management and the learning spaces literature,
} 
seem to provide one platform for less inhibited, intersecting avenues of development to be pursued. Importantly for social production, a range of particular, bounded activity systems operate within a wider 'substrate' that develops over a lengthy period of time.' (Bligh, 2014)

In fact, the experience of previous projects as described above helped to re-activate what Bligh (2014) and Engeström (2008) refer to as 'latent organisation', an expanding bundle of developing connections within a durable structure that may nonetheless remain apparently dormant for periods of time until being activated.'

\section{Successes:}

\section{Student Satisfaction}

One area where the Student Centre has exceeded expectations is the reception it received from students since it opened. Whilst feedback is not yet collated in a systematic way, anecdotal observations can be made on over 100 comments received. Amongst the positive comments, 31 related to emotions, 12 to facilities and 1 to services. Amongst the negative comments, 1 related to emotions, 15 to facilities and 1 to services. 7 related to behaviours, particularly other students using laptops at spaces with fixed computers or reserving spaces. One aspect of the feedback helped to vindicate the participative approach adopted with the Student Centre, seeking direct input from students to shape the detailed design and features within the building. Within the feedback, there were some unfamiliar words used, such as 'peng', illustrating the point that university administrators need to listen to understand the language of students. Indeed, the word has not yet been included in the dictionary while the OED themselves had launched an appeal to help identify the meaning of 'youth words' (Khan, 2018). According to Lexico, the adjective means 'very appealing, attractive, or impressive (used as a general term of approval)'. The majority of feedback to date has been emotive: the emphasis is not on the facilities or even services on offer, but on how 
the spaces make students feel. This is an important facet of learning spaces: based on the findings of Trigwell, Ellis and Han (2012) the emotions students feel about their university shape their approach to learning.

\section{Building a sense of community and showcasing talent}

The process of engaging students throughout the construction process has helped to set the Student Centre as the 'university living room' (Marmot, 2014). It is used for exhibitions of works by renown alumni, study space, student musical and artistic performances on show for students and members of the public.

Throughout the building, the design incorporates images drawn from UCL's Research Images As Art / Art Images As Research competition. These help to provide a sense of the research activity which happens across UCL, and brief descriptive panels provide information about the image to help foster cross-disciplinary curiosity for students in the building.

The ground floor of the Student Centre has been used for a variety of events involving UCL students, alumni and staff. For instance, to help promote the student elections in Spring 2019, a ball pit was installed by the Students' Union in the ground floor area adjacent to Gordon Street, with information about the elections to encourage engagement. The UCL Live Music Society and UCL Dance Society performed shortly after the building opened in the atrium space. The UCL Staff Choir also provides a termly performance. Other activities have included a Wellbeing event in partnership with the NHS, fortnightly Clothes Swap Shop to encourage waste reduction, as well as public engagement activities with secondary schools.

Permanent displays of public art in the Student Centre, alongside temporary exhibitions, enrich the physical and intellectual environment for the whole UCL 
community. The Student Centre showcases original artworks by UCL alumna and Turner Prize winner Rachel Whiteread and UCL academics Thomson \& Craighead.

\section{Challenges:}

\section{Continuity in student representation}

Sabbatical Officers from the Students' Union were members of Student Centre Project Board from July 2015 until the completion of the project. One of the challenges with maintaining student engagement over a period spanning multiple years is the change in representation, since Sabbatical Officers are elected annually. In order to sustain engagement over successive cohorts of student representatives, and maintain the levels of trust described above, the handover between Sabbatical Officers was critical and Library Services staff held joint meetings with outgoing and incoming representatives.

\section{Sustainability}

As the building reaches its first anniversary, UCL Estates and Library Services are planning a Post-Occupancy Evaluation (POE) to be conducted in 2020 to understand in detail the pros and cons of the building. It is hoped that the POE will involve input from The Bartlett and from UCL Arena, given academic expertise in these areas on teaching and learning spaces. Strelitz (2019) identifies how institutions can learn from successive POEs 'with the outputs of each study informing subsequent briefs and designs.' This is a relatively new process for UCL, although there is firm commitment from Estates, Library Services and other parts of the institution to ensure that the university learns lessons from each project.

UCL challenged themselves to design and operate an exceptionally sustainable building. Maintaining energy efficiency objectives against stretching goals and with a 
heavily-trafficked building will be a challenge. One precedent for a Student Centre with exemplary sustainable ambitions is the Saw Swee Hock Student Centre at the London School of Economics and Political Science (LSE): the building has proven extremely popular with students, however it failed to meet its energy objectives.

'despite its success as a social hub and as a superb piece of architecture, the fact remains that the Saw Swee Hock missed its own energy efficiency target. While it might now be seen as over-ambitious, stretching targets are important because they push design teams to perform. As modelling and measurement tools become more sophisticated, predicted and actual energy performance should start to fall into line.' (Hartman and Williams, 2019).

Marmot (2014) observed this disparity on a system-wide level: 'practice reveals that prediction of energy efficiency and carbon emissions can bear little resemblance to actual results of building performance. Carbon Buzz data $[\ldots]$ demonstrates that university educational buildings, on average, emit almost three times more carbon than predicted.' Time will tell whether the Student Centre can achieve its ambitious environmental targets.

\section{Conclusion}

UCL's Student Centre relates to the research-based education promoted by UCL in its inception and design: the academic mission of the university defines how the physical learning space and associated services were designed and organised.

The paper opened with a literature review to define research-based education and identify the active role of students implied by this model. The paper then referred to the UCL Cruciform Hub as a precedent illustrating the benefits of a participatory approach in creating a learning and teaching centre for Medical School students. The case study of the Student Centre shows the importance of trust between the university management, Estates, contractors and end users, including students. The experience of 
the Student Centre is that trust amongst the project team and stakeholders is critical to ensure that engagement can be conducted effectively and managed in a free-flowing manner as appropriate. Library services are well-placed to broker these relationships, as a typically trusted service within universities. The paper sets out how students' role in managing their own experience is crucial: where universities include students and staff as partners in shaping and managing learning space projects, evidence is growing that this leads to better pedagogical outcomes.

Finally, the paper highlighted some of the successes and challenges which emerged from the Student Centre, notwithstanding the limitations of the findings given the limited period of data collection to date. The building has elicited a strong emotional response from students, delivering heightened student satisfaction. It is also creating a stronger sense of belonging to the UCL community and nurturing students' engagement with their learning experience. Some of the key challenges relate to meeting heightened expectations from students, particularly when dealing with different generations of Student Sabbatical Officers for projects which span multiple years. This is an area which warrants exploring further, so that the insights of student representatives on major projects can be sustained without hindering student democracy on campus. The Student Centre has given a source of pride for UCL students and staff, and a tangible representation of what a research-based university looks and feels like for students. The building is referenced as a model for project management within the university and for the development of future learning space. A number of researchers from different institutions have initiated work to explore how students use the building, and hopefully findings will inform future theory and practice on learning space design and management. 
References

Arthur, Michael (2015) 'Provost's Perspective', MyUCL, 23 January.

https://www.ucl.ac.uk/news/students/012015/12015-23012015-

provostsperspective

Bacon, J. (2019) 'Stepping Up', Architecture Today, 297, April, 44-51. Retrieved from: http://www.architecturetoday.co.uk/stepping-up-3/. Accessed on 07/01/20

Beckers, R., van Der Voordt, T., Dewulf, G. (2016) 'Why do they study there? Diary research into students' learning space choices in higher education', Higher Education Research \& Development, 02 January, 35 (1), pp.142-157

Biesta, G. (2013) 'Balancing the core activities of universities: for a university that teaches' in Sugden, R., Valania, M. and Wilson, J.R. (eds.), Leadership and cooperation in academia: reflecting on the roles and responsibilities of university faculty and management. Cheltenham: Edward Elgar, pp. 32-4

Bligh, B. (2014) 'Examining New Processes for Learning Space Design' in in Temple, P. (ed.) The Physical University: Contours of Space and Place in Higher Education, Routledge, pp. 34-57

Brew, A. (2010) Imperatives and Challenges in Integrating Teaching and Research, Higher Education Research \& Development, 29:2, pp. 139-150

Burgess, A., Senior, C., Moores, E. (2018) 'A 10-year case study on the changing determinants of university student satisfaction in the UK', PLOS ONE, 13 (2): e0192976

Damşa, C., Nerland, M., Andreadakis, Z.E. (2019) 'An ecological perspective on learner-constructed learning spaces', British Journal of Educational Technology, 50 (5), pp. 2075-2089 
Ellis, R.A. and Goodyear, P. (2016) 'Models of learning space: integrating research on space, place and learning in higher education', Review of Education, 4 (2), pp. 149-191

Engeström, Y. (2008) From Teams to Knots: Activity-Theoretical Studies of Collaboration and Learning at Work, Cambridge and New York: Cambridge University Press

Fasshauer, I., Meyer, C., Bourret, C. (2015) 'De la participation à la coopération entre enseignants et étudiants dans le cadre d'un espace de coworking à l'université', Biennale Internationale de l'Education, de la Formation et des Pratiques Professionnelles. Paris, France

Fung, D. (2017) A Connected Curriculum for Higher Education. London: UCL Press

Geschwind, L. and Brostöm, A. (2015) 'Managing the Teaching-Research Nexus: Ideals and Practice in Research-Oriented Universities', Higher Education Research and Development, 34:1, pp. 60-73

Hartman, H., \& Williams, F. (2019). Saw Swee Hock five years on. Architects' Journal, 246 (3), pp. 41-55

Healey, M. (2005). Linking research and teaching: Exploring disciplinary spaces and the role of inquiry based learning. In R. Barnett (Ed.), Reshaping the university: New relationships between research, scholarship and teaching. London: McGraw Hill/Open University Press, pp. 67-78

Kahu, E.R. (2013) 'Framing student engagement in higher education', Studies in Higher Education, 38 (5), pp. 758-773

Khan, C. (2018) 'It's bare sick that the OED cares how young people speak', Guardian, 21 Sep. https://www.theguardian.com/commentisfree/2018/sep/21/oxfordenglish-dictionary-young-people-slang. Accessed on 10/01/20 
Krause, K-L (2009) 'Interpreting Changing Academic Roles and Identities in Higher Education' in Tight, M., Mok, K.H., Jeroen Huisman, J. and Morphew, C. (eds.) Routledge International Handbook of Higher Education. Abingdon, Oxon: Routledge, pp. 413-424

Kunian, F. (2004) 'Étude sur la participation des étudiants aux élections universitaires', Paris: Association Civisme et Démocratie (CIDEM)

Lucas, L. (2006) The Research Game in Academic Life. Maidenhead: Society for Research in Higher Education and Open University Press

Marie, J., Arif, M., Joshi, T. (2016) 'UCL ChangeMakers projects: supporting staff/student partnership on educational enhancement projects', Student Engagement in Higher Education Journal, 1 (1)

Marmot, A. (2014) 'Managing the Campus: Facility Management and Design, the Student Experience and University Effectiveness' in Temple, P. (ed.) The Physical University: Contours of Space and Place in Higher Education, Routledge, pp. 58-71

Meunier, B., Eigenbrodt, O. (2014) 'More Than Bricks and Mortar: Building a Community of Users Through Library Design', Journal of Library Administration, 54 (3), pp. 217-232

Neuman, D. (2003) 'Campus planning' in Neuman, D. (ed.), Building Type Basics for College and University Facilities, Hoboken, NJ: John Wiley \& Sons, pp. 1-44

"peng, adj.” (2019) Lexico, Oxford, https://www.lexico.com/definition/peng. Accessed on $20 / 01 / 20$.

Scott, P. (2014) 'Student experience' is the new buzzword, but what does it mean?', The Guardian, 4 February. https://www.theguardian.com/education/2014/feb/04/university-education-notjust-about-student-experience. Accessed on 10/08/19 
Scott, P. (2005) 'Divergence or convergence? The links between teaching and research in mass higher education', in Barnett, R. (ed.) Reshaping the university: New relationships between research, scholarship and teaching, Maidenhead: Society for Research into Higher Education and The Open University Press, pp. 53-66

Smyth, H. (2006) 'Measuring, developing and managing trust in relationships' in Pryke, S. and Smyth, H. (eds.) The Management of Complex Projects - a relationship approach, Oxford: Blackwell, 97-120

Strelitz, Z. (2019) 'How Is It For You? Building Design as Experienced by Users and Makers', Architectural Design, May, 89 (3), pp.60-67

Students' Union UCL (2020) Disability Discrimination Faced by UCL Students \& Recommended Measures - A UCL Disabled Students' Network Report, London: Students' Union UCL http://studentsunionucl.org/sites/uclu.org/files/u318399/documents/disabled_stu dents network report 2.pdf. Accessed on 21/01/20

Trigwell, K., Ellis, R.A., Han, F. (2012) 'Relations between students' approaches to learning, experienced emotions and outcomes of learning', Studies in Higher Education, 37 (7), pp. 811-824

UCL (2017) Education Strategy 2016-21. Principal Theme 2 of UCL 2034 https://www.ucl.ac.uk/teaching-learning/sites/teaching-learning/files/migratedfiles/ucl_education_strategy_june2017_finalv2_web.pdf. Accessed on 19/01/20

UCL (2014) UCL 2034: a new 20-year strategy for UCL https://www.ucl.ac.uk/2034/. Accessed on 19/01/20

UCL, Lifschutz, Davidson, Sandilands (2011) UCL Masterplan: Bloomsbury Campus. https://www.ucl.ac.uk/drupal/site transforming-ucl/sites/transformingucl/files/ucl-bloomsbury-masterplan-nov2011.pdf. Accessed on 19/01/20 
Universities UK (UUK) (2017) Education, Consumer Rights and Maintaining Trust. What Students Want from their University. London: UUK

Volker, L. (2008) 'Early design management in architecture' in Smyth, H. and Pryke, S. (eds.) Collaborative Relationships in Construction, Oxford: Wiley-Blackwell, pp. $179-196$

Volkmann, S., Stang, R. (2015) 'Global Trends in Physical Learning Space Research', Bibliothek Forschung und Praxis, Jun, 39 (2), pp. 235-239

Williams, F. (2019) The Student Centre, UCL, The Architects' Journal, Nov 21. p.82 